\title{
FREQUENCY OF MUSCULOSKELETAL AND EYE SYMPTOMS AMONG COMPUTER USERS AT WORK*
}

\author{
Bojana RADULOVIĆ ${ }^{1}$ and Azra HURŠIDIĆ-RADULOVIĆ ${ }^{2}$ \\ Institute for Emergency Medicine of the City of Zagreb ${ }^{1}$, Office for Occupational Medicine ${ }^{2}$, Zagreb, Croatia
}

Received in January 2012

CrossChecked in February 2012

Accepted in April 2012

\begin{abstract}
Computer users most often complain of the eye and locomotor system disorders. The goal of this paper was to find out the frequency and relation between musculoskeletal and eye symptoms among computer workers.

The data on musculoskeletal and eye symptoms were provided by two questionnaires.

Forty-nine workers were included in the study. Their mean age was 41 years and average length of service 16 years. The average amount of time they spent in front of computers was 6.73 hours per day. Women spent more time working at a computer per day than men $(\mathrm{P}=0.025)$. The most frequent complaint in the past year referred to the upper back pain (30.6 \% of the workers). Every fourth worker, i.e. $24.5 \%$ of them experienced neck pain in the past year; women more often than men $(\mathrm{P}=0.024)$. A health problem which reduced the range of motion and prompted the workers to ask for sick leave was lower back pain. The relation between eye symptoms and the upper back pain experienced in the past year $(\mathrm{P}=0.004)$, and in the last week $(\mathrm{P}=0.031)$ was statistically significant.

Proper exercises for stretching musculoskeletal system, ergonomic computer equipment, and artificial tears could decrease muscular and eye problems, which in turn could enhance productivity and reduce sick leaves.
\end{abstract}

KEY WORDS: computer, locomotor system disorders, video display, vision

Research shows that workers at video display terminals (VDT) mostly suffer from neck problems and upper and lower back pain but ergonomic interventions can reduce these difficulties $(1,2)$. Improper display height leads to faster and more pronounced trapezius muscle strain (3). To achieve the best ergonomic solutions, it is necessary to have a detailed analysis of worker's movements, which is nowadays provided by video technology (4).

Persons working with computers, who spend four or more hours on average in front of a computer screen,

* Partly presented at the $5^{\text {th }}$ Croatian Congress on Occupational Health with International Participation "Healt, Work, and Community", Hvar, Croatia, 28 September to 2 October 2011 must have previous preventive tests according to the legislative provisions (5). Eye problems and vision disorders related to working with computers are accompanied by the locomotor system-related diseases (6) and the goal of this paper was to find out the frequency and relation between the two.

\section{METHODS AND SUBJECTS}

The data on musculoskeletal disorders were provided by the Nordic Musculoskeletal Questionnaire (7). Eye problems related to work with computers, such as red eye, itching, excessive tearing, scratchiness, 
and eye burning, were provided by a previously used questionnaire (8). Ten percent of workers working in a factory were tested. All of them were administration workers who worked on computers for more than four hours per day. Statistical analysis was made using SPSS program, Version 8.0 for Windows. (1997, SPSS inc. Chicago, IL, USA). $\mathrm{P}<0.05$ was the statistically significant value for $t$ - test and chi-square tests (9).

\section{RESULTS}

Forty-nine middle aged workers (27 women and 22 men) were included in this study. Their average age was $(41.1 \pm 10.87)$ years and length of service $(16.37 \pm 11.29)$ years. The average amount of time they spent in front of computers was $(6.73 \pm 2.05)$ hours per day (Table 1). Statistically, there were no substantial differences in age and length of service between women and men. However, women worked longer hours at a computer per day than men $(\mathrm{P}=0.025)$. Table 2 shows that in the past year, workers mostly complained about pain and discomfort in the upper back (30.6\% of the subjects) and neck (every fourth worker or $24.5 \%$ of them; women more frequently than men) $(\mathrm{P}=0.024)$. Where last week's symptoms are concerned, $12.2 \%$ of women experienced neck pain. Pain in the neck and upper back did not significantly limit the range of motion. However, a health problem which reduced the range of motion and prompted the workers to ask for sick leave was lower back pain. Two workers experienced wrist pain with a limited range of motion indicative of the carpal tunnel syndrome. Eye symptoms like red eye, itching, excessive tearing, scratchiness, and burning were associated with 24 workers (49\%). Those with eye symptoms experienced significantly more pain and discomfort in the upper back in the past year $(\mathrm{P}=0.004)$, and in the last week $(\mathrm{P}=0.031)$ compared to other workers.

\section{DISCUSSION}

Our results showed that computer workers had frequent eye (49\%), upper back (31\%) and neck (24.5\%) symptoms. Lower back pain appeared in about $16 \%$ of subjects, which is less than in recent research (10). However, in our study, back pain was often a cause for sick leave, which was not the case with upper back or neck pain. Female computer users at work have their neck more often and longer exposed

Table 1 Data on subjects

\begin{tabular}{lccc}
\hline & \multicolumn{3}{c}{ Mean \pm SD } \\
\cline { 2 - 4 } & $\begin{array}{c}\text { Men } \\
(\mathbf{N}=\mathbf{2 2})\end{array}$ & $\begin{array}{c}\text { Women } \\
(\mathbf{N}=\mathbf{2 7})\end{array}$ & $\begin{array}{c}\text { Total } \\
(\mathbf{N}=\mathbf{4 9})\end{array}$ \\
\hline Age / years & $41.0 \pm 11.1$ & $41.2 \pm 10.9$ & $41.1 \pm 10.87$ \\
\hline Length of service / years & $15.0 \pm 10.5$ & $17.5 \pm 12.0$ & $16.37 \pm 11.29$ \\
\hline Daily working at computer / h & $5.9 \pm 2.5^{*}$ & $7.4 \pm 1.3^{*}$ & $6.73 \pm 2.05$ \\
\hline
\end{tabular}

* $P=0.025$, $t$-test

Table 2 Frequency of musculoskeletal symptoms

\begin{tabular}{lccc}
\hline & $\begin{array}{c}\text { Men } \\
\mathbf{N = 2 2} \\
\mathbf{n}(\mathbf{\%})\end{array}$ & $\begin{array}{c}\text { Women } \\
\mathbf{( N = 2 7 )} \\
\mathbf{n}(\mathbf{\%})\end{array}$ & $\begin{array}{c}\text { Total } \\
\mathbf{N = 4 9 )} \\
\mathbf{n}(\mathbf{\%})\end{array}$ \\
\hline Neck & $2(9.1)^{*}$ & $10(37.0)^{*}$ & $12(24.5)$ \\
\hline Symptoms in the last year & 0 & $6(22.2)^{* *}$ & $6(12.2)$ \\
\hline Symptoms in the last week & & & $11(40.7)$ \\
\hline Upper back & $4(18.2)$ & $6(22.2)$ & $15(30.6)$ \\
\hline Symptoms in the last year & $4(18.2)$ & & $10(20.4)$ \\
\hline Symptoms in the last week & & $5(185)$ & $8(163)$ \\
\hline Symptoms in the last year & $3(13.6)$ & $4(148)$ & $6(122)$ \\
\hline Symptoms in the last week & $2(91)$ & &
\end{tabular}

$* P=0.024$, chi-square test

$* * P=0.018$, chi-square test 
to strain than men (11), which was also pointed out in this paper. Troubles with the wrist and forearm appear to be less frequent musculoskeletal problems for computer users at work than neck and shoulder difficulties (1); the carpal tunnel syndrome was noticed only in two workers in our study.

Troubles in the upper back and neck were significantly associated with eye symptoms, which is indicative of the worker's job strain. Working at a computer for more than 36 hours per week is associated with increased anxiety, and with musculoskeletal and eye symptoms (12). Stress and mental strain increase the frequency of musculoskeletal problems. A recently published study showed that the workers sorting mail, who suffered from eyestrain, had a higher prevalence of musculoskeletal disorders (13).

In the past 20 to 25 years, the costs of sick leaves due to musculoskeletal problems have increased 3.5 times (14). Training workers, encouraging proper exercising, using artificial tears for relieving dry eye symptoms, and reducing the strain of musculoskeletal system with ergonomic equipment may reduce the frequency of eye and muscular troubles (15), which, as a result, could enhance productivity and reduce sick leaves.

\section{REFERENCES}

1. Spallek M, Kuhn W, Uibel S, van Mark A, Quarcoo D. Workrelated musculoskeletal disorders in the automotive industry due to repetitive work - implications for rehabilitation. J Occup Med Toxicol 2010;5:6.

2. Pillastrini P, Mugnai R, Bertozzi L, Costi S, Curti S, Guccione A, Mattioli S, Violante FS. Effectiveness of an ergonomic intervention on work-related posture and low back pain in video display terminal operators: a 3 year cross-over trial. Appl Ergon 2010;41:436-43.

3. Horikawa M. Effect of visual display terminal height on the trapezius muscle hardness: quantitative evaluation by a newly developed muscle hardness meter. Appl Ergon 2001;32:4738 .
4. Coenen P, Kingama I, Boot CR, Faber GS, Xu X, Bongers PM, van Dieën JH. Estimation of low back moments from video analysis: A validation study. J Biomech 2011;44:236975.

5. Pravilnik o sigurnosti i zaštiti zdravlja pri radu $\mathrm{s}$ računalom [The Regulation on Occupational Safety and Health Prevention of Computer Users, in Croatian]. Narodne novine 69/2005.

6. Knave BG, Wibom RI, Voss M, Hedström LD, Bergqvist UO. Work with video display terminals among office employees. I. Subjective symptoms and discomfort. Scand J Work Environ Health 1985;11:457-66.

7. Dickinson CE, Campion K, Foster AF, Newman SJ, O'Rourke AM, Thomas PG. Questionnaire development: an examination of the Nordic Musculoskeletal questionnaire. Appl Ergon 1992;23:197-201.

8. González-Méijome JM, Parafita MA, Yebra-Pimentel E, Almeida JB. Symptoms in a population of contact lens and noncontact lens wearers under different environmental conditions. Optom Vis Sci 2007;84:296-302.

9. Armitage P, Berry G. Statistical Methods in Medical Research. Oxford: Blackwell Science; 2000.

10. El-Bestar SF, El-Mitwalli AA, Khashaba EO. Neck-upper extremity musculoskeletal disordes among workers in the telecommmunications company at Mansoura City. Int J Occup Saf Ergon 2011;17:195-205.

11. Polanyi MF, Cole DC, Beaton DE, Chung J, Wells R, Abdolell M, Beech-Hawley L, Ferrier SE, Mondloch MV, Shields SA, Smith JM, Shannon HS. Upper limb work-related musculoskeletal disorders among newspaper employees: cross-sectional survey results. Am J Ind Med 1997;32:6208.

12. Tomei G, Rosati MV, Ciarrocca M, Capozzella A, Pimpinella B, Casale T, Monti C, Tomei F. Anxiety, musculoskeletal and visual disorders in video display terminal workers. Minerva Med 2006;97:459-66.

13. Hemphälä H, Eklund J. A visual ergonomics intervention in mail sorting facilities: effects on eyes, muscles and productivity. Appl Ergon 2012;43:217-29.

14. Deeney C, O'Sullivan L. Work related psychosocial risks and musculoskeletal disorders: potential risk factors, causation and evaluation methods. Work 2009;34:239-48.

15. Aarås A, Horgen G, Ro O, Løken E, Mathiasen G, Bjørset $\mathrm{HH}$, Larsen S, Thoresen M. The effect of an ergonomic intervention on musculoskeletal, psychosocial and visual strain of VDT data entry work: the Norwegian part of the international study. Int J Occup Saf Ergon 2005;11:25-47. 


\section{Sažetak}

\section{UČESTALOST MIŠIĆNO-KOŠTANIH I OČNIH SIMPTOMA KOD RADA S RAČUNALOM}

Kod rada s računalom javljaju se tegobe vezane uz oči i lokomotorni sustav. Cilj je rada utvrditi učestalost tegoba očiju i mišićno-koštanoga sustava kod radnika koji rade s računalom i njihovu povezanost. Pomoću upitnika uzeti su podaci o mišićno-koštanim i očnim simptomima kod rada s računalom. U ispitivanju je sudjelovalo 49 radnika (27 žena i 22 muškarca) prosječne životne dobi od 41 godina i prosječnog trajanja radnog staža od 16 godina koji dnevno rade za računalom u prosjeku 6,73 sata. Žene su značajno duže dnevno radile na računalu od muškaraca $(\mathrm{P}=0,025)$. Najviše se radnika žalilo na bolove u gornjem dijelu leđa u zadnjih godinu dana (30,6 \%). Svaki četvrti radnik, tj. 24,5 \% radnika imalo je bol u vratu u zadnjoj godini i to statistički značajno češće žene $(\mathrm{P}=0,024)$. Tegobe koje ograničavaju aktivnost i mogu zahtijevati bolovanje bili su bolovi u donjem dijelu leđa. Statistički je bila značajna povezanost pojave očnih simptoma i bolova u gornjim leđima u zadnjoj godini $(\mathrm{P}=0,004)$ i u zadnjem tjednu $(\mathrm{P}=0,031)$. Odgovarajuće vježbe rasterećenja mišićno-koštanoga sustava uz ergonomsku opremu za rad s računalom te smanjenje očnih tegoba upotrebom umjetnih suza potrebno je provoditi radi smanjenja mišićnih i očnih tegoba, što zajedno povećava produktivnost i smanjuje bolovanja.

KLJUČNE RIJEČI: mišićno-koštani poremećaji, računalo, vid, videoterminal

\section{CORRESPONDING AUTHOR:}

Radulović Bojana, dr. med.

Trg žrtava fašizma 11,10000 Zagreb

E-mail: bojanara84@yahoo.com 